\title{
ANALISIS MOTIVASI BELAJAR PADA SISWA ADHD (ATTENTION DEFICIT HYPERACTIVITY DISORDER) DI SD NEGERI 023 SAMARINDA UTARA
}

\author{
Nur Agus Salim, Andi Aslindah, Eka Selvi Handayani, Arista Damayanti \\ Universitas Widya Gama Mahakam Samarinda \\ nuragussalim@uwgm.ac.id, aslindah.andirezky@yahoo.com, ekaselvi16@gmail.com
}

\begin{abstract}
This study intended to determine the background of learning motivation of ADHD (Attention Deficit Hyperactivity Disorder) students. Besides knowing how to handle ADHD students and whatever factors that influence learning motivation. This was a qualitative descriptive study and the research subjects comprised 5 ADHD students, parents and homeroom teachers. The research instrument used observation sheets, interview sheets, and cameras. Data analysis technique was done by obtaining data from the field going to observation, interviews, and documentation, data reduction, data presentation then drawing conclusions. The sampling technique uses snowball sampling techniques and uses source triangulation and triangulation techniques. The results showed that the background of ADHD students' learning motivation tends to be minimal compared to students. Due to the condition of ADHD students have three symptoms, hyperactivity, intention and impulsivity. With this symptom condition, ADHD students must get a special approach such as more attention and be able to handle it without taking rough actions or punishing because it can affect the mental condition in ADHD students.
\end{abstract}

Keywords: Learning Motivation, ADHD Students

ABSTRAK
Penelitian ini bertujuan untuk mengetahui latar belakang motivasi belajar siswa ADHD (Attention Deficit Hyperactivity Disorder) di SD Negeri 023 Samarinda Utara. Selain itu untuk mengetahui cara penanganan siswa ADHD serta faktor-faktor apasaja yang mempengaruhi motivasi belajarnya. Jenis penelitian ini adalah penelitian deskriptif kualitatif. Subjek penelitian terdiri dari 5 siswa ADHD, orang tua dan guru wali kelas. Instrumen penelitian menggunakan lembar observasi, lembar wawancara, dan kamera. Teknik pengumpulan data observasi, wawancara, dan dokumentasi. Teknik analisis data dilakukan dengan cara memperoleh data dari terjun ke lapangan langsung dengan melakukan observasi, wawancara, dan dokumentasi, reduksi data, penyajian data lalu penarikan kesimpulan. Teknik pengambilan sampel menggunakan teknik snowball sampling dan menggunakan triangulasi sumber dan triangulasi teknik. Hasil penelitian menunjukkan bahwa latar belakang motivasi belajar siswa ADHD cenderung minim dibandingkan dengan siswa pada umumnya. Dikarenakan kondisi siswa ADHD memiliki tiga gejala yaitu hyperactivity, Inatensi dan Impulsif. Dengan kondisi gejala seperti itu siswa ADHD harus mendapatkan pendekatan khusus seperti perhatian lebih dan dapat menanganinya dengan sabar tanpa melakukan tindakan kasar atau menghukum karena bisa mempengaruhi kondisi mental dalam diri siswa ADHD

Kata Kunci : Motivasi Belajar, Siswa ADHD

\section{PENDAHULUAN}

Sekolah dasar merupakan suatu lembaga pendidikan yang mempunyai tujuan untuk diselenggarakan agar dapat mengembangkan pengetahuan, sikap, kemampuan dan keterampilan dasar peserta didik untuk menyesuaikan dirinya di dalam maupun di luar lingkungan. Disamping itu, pendidikan di sekolah dasar juga dapat membantu perkembangan dan pertumbuhan jasmani dan rohani peserta didik untuk meneruskan pendidikan selanjutnya kejenjang yang lebih tinggi. Peran guru sangat penting dalam mengarahkan dan membimbing siswa-siswinya. Pada saat kegiatan belajar mengajar, apabila ada seseorang siswa misalnya berbuat sesuatu yang tidak seharusnya dikerjakan, maka perlu 
diselediki sebab-sebabnya. Sebab-sebab itu biasanya bermacam-macam seperti anak yang susah untuk diam ditempat duduk, sulit untuk memusatkan perhatiannya, suka membuat onar di dalam kelas dan susah untuk diberi tahu. Keadaan semacam itu perlu dilakukan upaya yang dapat menemukan sebab terjadinya. Kemudian mendorong seorang siswa untuk mau melakukan pekerjaan yang harus dikerjakan, yakni belajar dan bersifat sopan kepada guru. Dengan kata lain, siswa perlu diberikan rangsangan agar tumbuh motivasi pada dirinya atau lebih tepatnya perlu diberikan motivasi belajar. Dengan memberikan motivasi belajar agar anak didik dapat melakukan aktivitas belajar dengan baik.

Mendidik anak adalah suatu hal yang tidak mudah. Mungkin saja seseorang bisa membuat anak menjadi pintar tetapi untuk mendidik anak agar memiliki emosi yang stabil sangatlah susah. Sebab, tidak semua orang dapat mengontrol emosi seorang anak. Diperlukan sosok orang tua dan guru yang memiliki sifat sabar serta mempunyai semangat dedikasi yang tinggi untuk bisa lebih memahami kepribadian seorang anak. Ketika awal memasuki dunia pendidikan yaitu Sekolah Dasar guru akan menemukan berbagai macam karakteristik seorang anak yang berbeda-beda tingkah lakunya bahkan tingkat kemampuannya. Ada anak yang cenderung pendiam, suka menyendiri di dalam kelas, pemalu, susah diajak untuk berkomunikasi, ada yang bekerja dengan lamban, ada anak yang aktif di dalam kelas bahkan ada pula anak yang memiliki sifat hyperactivity dan impulsif. Maka dari itu dalam proses belajar mengajar, guru dihadapkan pada kenyataan bahwa banyak sekali ditemukan keanekaragaman individu siswa. Dengan keanekaragaman tersebut maka penguasaan hasil belajar beranekaragam juga.

Seiringan kemampuan anak seusia sekolah dasar terdapat juga anak yang memiliki gejala ADHD, yaitu inatensi gejala anak yang susah memusatkan perhatian atau susah untuk berkonsentrasi serta sangat sulit dikendalikan emosinya bahkan para guru banyak yang mengeluh mengatasinya. Siswa yang sulit untuk diatur dan terkesan suka menimbulkan keributan di dalam kelas atau tidak bisa diam termasuk anak ADHD dengan gejala (hyperctivity). Sehingga motivasi belajar anak ADHD juga tidak dapat maksimal seperti anak yang lainnya. Maka dari itu dibutuhkan pendekatan khusus untuk meningkatkan motivasi belajar anak ADHD agar dapat memaksimalkan potensi belajarnya dengan baik. Solusi pendekatannya dapat berupa bimbingan atau treatment yang sesuai dengan kebutuhan mereka (Kewley \& Latham, 2010). Sehingga semua anak berhak mendapatkan pendidikan yang terbaik sesuai kemampuan dan kesulitan mereka masing-masing.

Berdasarkan hasil observasi yang telah dilakukan oleh peneliti bahwa anak yang memiliki gejala ADHD cenderung terlihat lebih hyperactivity di dalam kelas seperti tidak bisa diam, suka berlari-lari, banyak bergerak dan tidak betah untuk diam di tempat duduknya tidak seperti anak yang lainnya. Bahkan anak ADHD juga memiliki gejala susah untuk memusatkan perhatiannya seperti susah diajak berbicara dan lambat untuk mengerjakan soal yang diberikan oleh gurunya. Serta sifat impulsif yaitu suka melakukan sesuatu hal dengan sesuka hatinya seperti mengganggu dan memukul temannya, mencoret buku dan membuang barang temannya, tidak bisa sabar untuk menunggu giliran, dan berani memotong pembicaraan guru. Maka dari itu sangat diperlukan peran orang tua dan guru dalam memberikan motivasi belajar agar anak ADHD bisa tumbuh dan berkembang seperti anak yang lainnya. Motivasi belajar sangat penting diberikan karena berguna untuk membangkitkan semangat dalam diri anak ADHD agar dapat belajar lebih giat.

\section{KAJIAN PUSTAKA}

\subsection{Kajian Motivasi Belajar}

\subsubsection{Pengertian Motivasi Belajar}

Menurut Elsjelyn (2014) Motivasi

belajar dapat diartikan sebagai dorongan yang berada di dalam diri seseorang yang dapat memacu orang tersebut untuk melakukan sesuatu hal yang didasari oleh tujuan yang hendak ingin dicapai. Apabila tujuan itu jelas dan menarik, maka orang tersebut akan mempunyai motivasi yang kuat untuk melakukan sesuatu hal yang dapat mencapai tujuannya. Misalnya, anak yang belum lancar membaca maka ia akan termotivasi untuk giat belajar membaca agar bisa naik kelas. 
Menurut Badaruddin (2015) motivasi belajar merupakan pendorong psikis yang dapat merubah energi pada diri seseorang untuk terus semangat dan dapat bertahan untuk terus menggapai tujuan yang akan dicapai. Pada dasarnya motivasi belajar yakni dorongan yang bersifat internal dan eksternal pada siswa untuk meningkatkan perubahan tingkah laku seperti meningkatkan hasil belajarnya, mencapai suatu kebutuhan atau keinginan yang berhasil, adanya cita-cita atau suatu harapan di masa depan serta adanya kegiatan pembelajaran yang menarik dan kondusif sehingga memungkinkan siswa untuk belajar dengan baik.

Motivasi juga dapat diketahui dengan perubahan yang dialami oleh seseorang, akibat timbulnya perasaan, emosi dan kejiwaan sehingga dapat membangkitkan individu agar melakukan atau bertindak sesuai dengan kebutuhannya untuk mencapai suatu tujuan (Dayana \& Marbun, 2018). Dapat diartikan sebagai letupan atau dorongan pada diri seseorang yang dapat membangkitkan semangat untuk mengeluarkan hal-hal yang terbaik dalam dirinya. Misalnya dalam proses kegiatan belajar di kelas, motivasi memiliki peran yang dapat menjamin keberlangsunga kegiatan belajar dan memberikan arah sehingga tujuan yang ingin dicapai dapat terpenuhi. Dengan demikian motivasi belajar sangat berpengaruh terhadap hasil belajar seseorang. Apabila seseorang tidak memiliki motivasi untuk belajar, maka orang tersebut tidak dapat mencapai hasil belajar yang optimal.

Berdasarkan pendapat para ahli di atas maka dapat disimpulkan bahwa pengertian motivasi belajar merupakan pendorong yang dapat menggerakan minat belajar dalam diri siswa untuk lebih baik agar bisa belajar dengan sungguh-sungguh untuk mencapai tujuan proses pembelajaran. Jika siswa memiliki pendorong motivasi yang tinggi dari peran guru dan orang tua maka siswa tersebut mengalami perubahan yang signifikan yaitu menjadi sosok individu yang mau belajar untuk menjadi yang lebih baik. Dan sebaliknya jika seseorang tidak memiliki motivasi dalam dirinya maka hasil kegiatan belajarnya tidak akan mencapai hasil yang optimal.

\subsubsection{Fungsi Motivasi Belajar}

Menurut Sardiman (2014) motivasi belajar juga memiliki beberapa fungsi sebagai berikut:

a. Bisa mendorong manusia untuk lebih bisa bergerak melakukan suatu hal dengan baik maupun lebih maju dari sebelumnya. Seperti adanya peningkatan hal yang positif di dalam hidupnya, contohnya anak yang tidak pernah mendapatkan juara kelas tetapi dia memiliki motivasi belajar yang tinggi untuk giat dan rajin belajar maka anak tersebut bisa mendapatkan juara kelas.

b. Dapat menentukan arah perbuatan, seperti menuju arah ke suatu tujuan yang hendak ingin dicapai. Dengan demikian motivasi dapat menuntun atau memberikan arah kegiatan yang harus dikerjakan sesuai dengan tujuannya yang hendak ingin dicapai. Contohnya seperti anak yang mempunyai cita-cita ingin menjadi atlit bulu tangkis yang hebat maka anak tersebut harus menanamkan motivasi di dalam dirinya untuk giat dan rajin berlatih olahraga bulu tangkis agar menjadi atlit yang hebat.

c. Dapat memilah-milah suatu perbuatan. Seperti dapat menentukkan perbuatan yang harus dikerjakan yang selaras dengan tujuan sesuatu yang ingin dicapai, juga dapat menyisihkan perbuatan yang tidak bermanfaat bagi tujuan tersebut. Dengan demikian seseorang harus paham pekerjaan yang tidak menghasilkan energi yang positif seperti tidak bermanfaat dalam dirinya lebih baik tidak dikerjakan dan lebih fokus untuk mewujudkan suatu pekerjaan yang hendak ingin dicapai.

Dalam suatu kegiatan belajar mengajar, motivasi sangat diperlukan guna untuk menunjang tingkat tinggi rasa semangat peserta didik untuk melakukan proses pembelajaran di kelas. Sebab, jika seseorang tidak memiliki motivasi dalam belajarnya maka cenderung tidak bisa lebih cepat menangkap daya pengetahuan yang diberikan oleh gurunya. Karena dengan adanya motivasi dalam diri siswa ketika mengikuti proses belajar mengajar maka hasil belajarnya akan optimal. Makin tepatnya motivasi yang diberikan makin tinggi pula tingkat keberhasilan siswa tersebut. Jadi motivasi senantiasa menentukan kualitas belajar siswa. Oleh karena itu, guru dan orang tua harus mampu meningkatkan 
motivasi belajar siswa, salah satunya dengan melalui pendekatan yang khusus.

\subsection{Kajian Anak ADHD ( Attention Deficit Hyperactivity Disorder )}

\subsubsection{Pengertian Anak ADHD}

ADHD merupakan istilah dari kepanjangan Attention Deficit Hyperactivity Disorder. Jika diartikan ke dalam bahasa Indonesia menjadi Gangguan Pemusatan Perhatian disertai hyperactivity bisa juga menggunakan istilah GPPH tapi lebih dikenal dan sering disebut sebagai ADHD. Jadi, dapat diartikan bahwa ADHD merupakan gangguan pada anak-anak yang memiliki tiga ciri utama yaitu yang pertama inatensi (rentang perhatian yang kurang) seperti susah diajak berbicara dan sulit untuk berkonsentrasi terhadap suatu pekerjaan, yang kedua impulsif yaitu perilaku yang tidak disertai dengan pemikiran terlebih dahulu contohnya seperti suka mengganggu dan memukul temannya, suka memotong pembicaraan dan melawan guru, suka membuang barang orang lain. Dan yang ketiga hiperaktif merupakan gerakan yang berlebihan susah untuk diam seperti tidak bisa menahan gerakan tubuhnya. Tidak memiliki rasa lelah untuk terus bergerak melompat, memanjat pohon atau tembok seperti melakukan hal-hal yang tidak penting (Tiel, 2018).

Jika didefinisikan, secara umum ADHD adalah kondisi anak yang memperlihatkan ciri atau gejala inatensi yang susah untuk memusatkan perhatiannya seperti kurangnya konsentrasi, hyperactivity yang memiliki gerakan berlebihan tidak bisa diam, dan impulsif sifat yang sesuka hatinya untuk melakukan sesuatu hal yang dapat menyebabkan terjadinya ketidakseimbangan sebagian besar kegiatan hidup mereka. Sehingga proses dalam pembelajaran dapat terganggu jika anak hyperactivity dan impulsif yang sering menimbulkan kekacauan atau keributan di dalam kelas untuk mengajak teman-temannya berlarian, berjalan-jalan mendatangi tempat duduk temannya untuk diganggu, tidak sabaran untuk menunggu giliran, suka melawan perkataan guru. Sedangkan inatensi yaitu sulitnya memusatkan perhatian seperti lambat untuk mengerjakan tugas yang diberikan oleg guru, susah untuk diajak berbicara, suka melamun dan diam. (Baihaqi \& Sugiarmin, 2014).

Menurut Rejeki (2014) mengartikan bahwa ADHD adalah gangguan perkembangan aktivitas anak-anak yang menyebabkan aktivitas yang cenderung berlebihan seperti gerakan yang tidak stabil pada anak-anak lainnya, yang ditandai dengan berbagai keluhan perasaan gelisah, tidak bisa diam, melakukan sesuatu tanpa melakukan pemikiran terlebih dahulu, susah untuk berkonsentrasi pada saat proses pembelajaran, suka melamun, pikirannya terngiang-ngiang tidak fokus pada saat proses belajar, susah untuk diajak berkomunikasi, tidak dapat menyelesaikan tugas yang telah diberikan oleh guru cenderung susah untuk berpikir.

Jadi, dapat disimpulkan dari beberapa pendapat para ahli di atas. ADHD merupakan gangguan pemusatan perhatian (attention problems) seperti susah untuk diajak berbicara, lamban dalam mengerjakan tugas, suka diam seperti melamun, disertai pula dengan perilaku yang berlebihan (Hyperactivity) seperti terlalu banyak gerak yang berlebihan contohnya suka berlari-lari di dalam kelas, tidak bisa duduk diam, suka menimbulkan keributan dan yang terakhir yaitu impulsif yakni perilaku yang dilakukan dengan sesuka hatinya seperti mengganggu dan memukul temannya, suka memotong pembicaraan guru, suka melawan guru.

\section{METODE PENELITIAN}

Desain penelitian ini menggunakan jenis penelitian deskriptif kualitatif. Penelitian deskriptif adalah penelitian untuk mendapatkan gambaran yang lebih jelas tentang fenomena-fenomena yang terjadi dalam kaitannya dengan masalah yang diteliti. Tempat penelitian dilakukan di SD Negeri 023 Samarinda Utara, yang beralamat jalan Perum Solong Durian Kelurahan Sempaja Selatan Kecamatan Samarinda Utara. Waktu penelitian dilaksanakan pada bulan April sampai Juli 2019. Subjek penelitian kualitatif ini adalah siswa ADHD, guru dan orang tua siswa ADHD di SD Negeri 023 Samarinda Utara. Jumlah siswa yang akan diteliti yaitu 5 siswa laki-laki yang terdiri 2 siswa ADHD Hyperactivity, 2 siswa ADHD Inatensi dan 1 siswa ADHD Gabungan, guru wali dari kelas I A, II C, IV A serta orangtua dari setiap siswa ADHD. 
Penelitian ini menggunakan teknik analisis data yang ada dengan model interaktif Miles and Huberman. Aktivitas dalam analisis data pada penelitian ini terdiri dari empat komponen yang saling berinteraksi, yaitu pengumpulan data, reduksi data, penyajian data, dan penarikan kesimpulan.

\section{HASIL PENELITIAN DAN PEMBAHASAN}

Hasil penelitian merupakan uraian data-data yang telah diperoleh dari hasil penelitian lapangan yang sesuai dengan kejadian nyata yang telah diamati oleh peneliti untuk memfokuskan masalah yang ada didalam skripsi. Berdasarkan fokus penelitian dalam penelitian ini, maka peneliti memaparkan hasil data yang telah diperoleh berkaitan dengan perilaku anak ADHD ketika di sekolah dan di rumah selanjutnya teknik guru dan orang tua dalam menangani anak ADHD selanjutnya kendalanya serta solusi untuk menanganinya dan yang terakhir cara menumbuhkan motivasi belajar di dalam diri anak ADHD. Selain itu hasil penelitian yang berkaitan dengan hasil penelitian ini adalah mengungkapkan data yang telah didapat pada saat dilapangan baik berupa observasi, wawancara, maupun dokumentasi.

\subsubsection{Partisipan 1 (Anak ADHD Hyperactivity)}

Partisipan pertama dalam penelitian ini adalah M. Fatir Aldi Saputra. Seorang siswa laki-laki yang berumur 7 tahun lebih yang mengalami gejala ADHD yaitu hyperactivity yang duduk di kelas I A. Peneliti mengetahui tentang keseharian Fatir selama di sekolah dari wali kelas yang menceritakan bahwa Fatir tergolong siswa ADHD tipe Hyperactivity ringan. Yang dimaksud hyperactivity ringan yaitu gejala yang tidak terlalu serius di dalam diri Fatir. Sebab, Fatir masih bisa dikontrol emosinya dan jika ditegur oleh guru masih mendengarkan walau akan diam hanya beberapa menit saja. Setelah itu Fatir akan kembali lagi ribut lari kesana kemari saat jam pelajaran, mendatangi tempat duduk temannya satu persatu, bersembunyi di kolom meja, usil mengganggu temannya yang sedang menulis atau mengerjakan tugas sehingga dia lama selesai dalam mengerjakan tugas yang diberikan oleh guru.

Awal bulan Agusutus 2018 tepatnya tahun kemaren, peneliti mempunyai kesempatan memulai PPL di SD Negeri 023 Samarinda Utara dan sempat beberapa kali masuk untuk mengajar di kelas IA. Saat itu peneliti menggantikan wakil kelas yang sedang pergi ke luar kota. Pada saat PPL peneliti memang mengalami kesulitan menghadapi Fatir yang tidak bisa duduk dengan tenang selalu saja berjalan-jalan mengelilingi kelas dan mendatangi tempat duduk temannya satu persatu untuk diajak mengobrol, bermain atau mengganggu temannya yang sedang menulis. Waktu itu peneliti hanya bingung bagaimana cara menangani anak tersebut yang tidak bisa diam di tempat duduknya. Dari pengalaman PPL lah peneliti mengetahui adanya anak hyperactivity seperti yang di alami oleh Fatir.

Pada tanggal 13 April 2019, peneliti berkesempatan masuk di kelas Fatir untuk melakukan observasi pada saat proses pembelajaran berlangsung. Gunanya untuk membuktikan apakah Fatir masih mengalami gejala ADHD hyperactivity. Dan pada saat observasi tersebut peneliti mengamati Fatir yang masih bertingkah seperti anak yang susah untuk diam. Bukannya berkurang, tingkah hyperactivity Fatir semakin parah. Dia mulai pintar mencari alasan untuk pergi ke WC alasannya buang air kecil, suka keluar masuk kelas alasannya meraut pensil bukan hanya sekali dua kali tapi bisa lebih dari empat kali meraut pensil. Sampai gurunya pun menyuruh Fatir untuk duduk di depan meja guru agar tidak mencari alasan untuk berjalan-jalan atau izin keluar masuk kelas..

Yang telah peneliti dapatkan saat mengamati Fatir, ia merupakan sosok anak yang mudah berinteraksi karena dia mempunyai banyak teman walaupun kadang Fatir suka usil menggangu temannya, tetapi disisi lain Fatir memiliki sifat yang peduli terhadap temannya seperti suka menolong temannya yang lagi kehilangan barang dia akan senantiasa membantu mencari, bahkan Fatir suka membelikan temannya jajan jika uang sakunya masih sisa banyak atau dia berbagi makanan untuk dimakanan bersama.

Pada tanggal 3 Mei 2019, peneliti melakukan wawancara bersama Fatir. Pada saat wawancara peneliti lebih cenderung menanyakan tentang kebiasaanya di rumah dan alasan dia kenapa suka lari-lari di dalam kelas. Hasil dari wawancara bersama Fatir yaitu dia anak yang rajin jika ada di rumah tetapi harus diberikan perhatian khusus 
seperti saat belajar harus ditemanin agar fokus belajarnya. Fatir merupakan anak yang lumayan pintar di dalam kelas hanya saja tingkah dia yang begitu berlebihan tidak bisa diam sehingga sering ketinggalan mengerjakan tugas. Pada saat diberikan pekerjaan rumah Fatir merupakan siswa yang rajin selalu mengerjakannya. Dia juga termasuk siswa yang cepat dalam menangkap pelajaran karena nilainya selalu lumayan bagus. Maka dari itu, wali kelas Fatir berinisiatif menambah jam tambahan kepada Fatir sekitar lima belas menit atau dua puluh menit setelah jam pulang sekolah karena Fatir selalu tidak tepat waktu saat menyelesaikan tugas yang diberikan ibu guru.

Pada tanggal 12 Mei Peneliti berkesempatan untuk mewawancarai guru kelas I A yaitu Ibu Sri. Saat peneliti menyampaikan beberapa asumsi tentang anak ADHD bu Sri tidak mengetahui apa itu ADHD hanya tahu gejalanya saja, bahwa anak tersebut hyperactivity atau anak tersebut susah menangkap pelajaran. Pada saat saya menanyai tentang Fatir bu Sri menjelaskan tingkah hyperactivity Fatir yang susah kadang untuk dikendalikan. Fatir bukan sosok siswa yang parah dalam artian masuk ke dalam anak kebutuhan khusus. Gejala ADHD hyperactivity Fatir termasuk ringan karena tidak pernah sampai melompat-lompat di atas meja atau memanjat-manjat pohon. Dan Fatir termasuk siswa yang jika diberi teguran diam tidak melawan walaupun diamnya hanya beberapa menit lalu diulanginya kembali. Bu Sri hanya kesusahan jika Fatir mulai suka menganggu temannya saat mengerjakan tugas karena bisa menghambat proses pembelajaran yang menyebabkan semakin lama menyelesaikan tugasnya.

Tepat hari senin tanggal 20 Mei 2019, peneliti menemui orang tua Fatir yaitu ibu Yayuk Asniah seorang ibu rumah tangga. Beliau sekitar umur 45 tahun dan Fatir adalah anak terakhir dari 2 bersaudara. Setiap pergi ke sekolah Fatir selalu dititipkan kepada pamannya dan saat pulang sekolah kadang Fatir pulang sendiri atau ikut orang tua temannya karena ibu Fatir tidak bisa membawa motor dan bapaknya harus kerja. Pada saat di rumah Fatir merupakan anak yang banyak gerak, dikala sakit saja Fatir bisa diam. Dia termasuk anak yang rajin jika waktunya belajar, tetapi harus ditemani jika tidak dia akan mainan atau berlari lari kesana kemari.

Di rumah Fatir merupakan adik yang baik karena selalu rukun terhadap kakaknya jarang sekali berkelahi. Pekerjaan rumah yang dibiasakan oleh orang tua Fatir adalah membersikan tempat tidur, menyimpun kembali buku pelajaran dan mainan yang sudah dihamburnya. Impian kedua orang tua Fatir yaitu "Walaupun Fatir termasuk anak ADHD gejala hyperactivity ringan, tetapi kedua orangtua Fatir berharap dia tumbuh menjadi anak yang pintar dan cerdas serta bisa mandiri dan sholeh". Motivasi yang ibu Yayuk berikan kepada Fatir yaitu seperti mengingatkan Fatir harus rajin mengaji jika ingin menjadi anak sholeh, harus rajin belajar jika ingin menjadi orang yang sukses. Karena Fatir sosok anak yang semangat jika diberi pujian maka dari orang tua Fatir itu sering memberikan pujian setiap apa yang telah Fatir kerjakan

\subsubsection{Partisipan II (Anak ADHD Inatensi)}

Partisipan kedua dalam penelitian ini adalah siswa laki-laki berumur 7 tahun di kelas IA yang bernama Maulana Jalauddin Rumi. Rumi mengalami gejala ADHD gejala Inatensi yaitu anak yang sangat pendiam, susah dalam berkomunikasi, dan berkonsentrasi dalam hal pembelajaran di kelas. Rumi merupakan sosok anak yang sangat sedikit sekali berbicara, hari-harinya dihabiskan untuk melamun dan diam saja di dalam kelas. Berbeda dari teman-temannya yang lain yang suka bercanda, bermain sedangkan Rumi memilih untuk diam ditempat duduknya sambil melamun. Untuk berkomunikasi dengan Rumi harus diulangulang agar dia paham apa yang sedang kita tanyakan ke dia. Karena dia susah untuk berkonsentrasi terhadap hal apapun.

Pada tanggal 22 April peneliti mendapatkan kesempatan untuk melakukan observasi terhadap Rumi. Dari pengamatan yang didapat dari observasi peneliti juga pernah PPL dibulan Agustus 2018 kemaren berkesempatan mengajar di kelas Rumi untuk menggantikan wali kelas yang sibuk pergi ke luar kota. Dari pengamatan saat PPL Rumi memang sosok anak yang tidak banyak gerak dan berbicara. Dia hanya diam dan melamun ditempat duduknya. Mengajak berbicara kepada Rumi pun harus dekat dan diulang beberapa kali agar dia paham. Dalam 
mengerjakan tugaspun dia sangat lambat karena tidak bisa berkonsetrasi pikirannya melayang-layang dan lamban dalam berpikir. Untuk berinteraksi terhadap temanpun Rumi tidak pernah maka dari itu dia tidak memiliki teman yang dekat. Waktunya hanya dihabiskan dengan kesibukannya sendiri yaitu melamun dan diam.

Dia sosok anak yang tidak pernah usil seperti mengganggu temannya atau membuat keributan di kelas. Bahkan temannya yang suka mengganggu dia, dia hanya menangis tanpa ada perlawanan atau mengadu ke guru dia tidak pernah. Peneliti bertemu dengan Rumi sedikit kesusahan karena dia jarang sekali masuk sekolah. Bisa dihitung seminggu Rumi masuk sekolah hanya dua atau tiga kali saja selebihnya dia tidak masuk sekolah tanpa keterangan.

Hari sabtu tepatnya tanggal 12 Mei 2019, peneliti melakukan wawancara bersama guru wakil kelas I A yaitu Ibu Sri. Dari yang telah Ibu Sri sampaikan kepada peneliti memang benar adanya bahwa Rumi memang anak ADHD dengan gejala inatensi. Rumi termasuk siswa peringkat terakhir dari 23 siswa. $\mathrm{Bu}$ Sri mengaku kualahan menghadapi si Rumi. Memang benar Rumi tidak pernah melakukan keributan, kenakalan atau mebuat onar di dalam kelas. Tetapi, dia anak yang sangat pendiam sangking pendiamnya susah sekali berkomunikasi dengan dia. Sebagai guru ibu Sri bingung apa yang sedang dialami dan dipikirkan oleh Rumi. Dia sering tidak masuk sekolah, PR tidak pernah dikerjakan, datang selalu terlambat, mengerjakan tugas di kelas selalu tidak pernah selesai.

Sampai akhirnya Ibu Sri memberikan jam tambahan setelah pulang sekolah untuk Rumi sekitar 10 sampai 15 menit. Karena Rumi tidak pernah menyelesaikan tugas dan belum bisa membaca,huruf abjad saja Rumi tidak hafal. Orang tua Rumi selalu menjemput terlambat sampai siang-siang bahkan kadang dia menunggu sambil tiduran di lapangan volly deket sekolah. Bu Sri sudah sering kali menyuruh Rumi untuk menunggu di UKS sekolah ketika orang tuanya belum menjemput tapi dia tidak mendengarkan, dia lebih senang menunggu dibawah pohon dekat lapangan volly. Dia seperti orang asing yang asik sendiri dengan dunianya. Bu Sri juga sering memberikan motivasi belajar terhadap Rumi agar tidak tertinggal dari teman- temannya yang lain. Kadang juga bu Sri mengancam jika Rumi terus menerus malas tidak mengerjakan tugas dan malas masuk sekolah Rumi tidak akan naik kelas. Tanggapan Rumi mendengarkan ancaman seperti itu hanya diam saja tanpa ekspresi apapun.

Peneliti melakukan wawancara terhadap Rumi tepat hari selasa tanggal 14 Mei 2019. Pertemuan peneliti dengan Rumi sangat sulit karena faktor dimana Rumi sering sekali tidak masuk sekolah. Peneliti mengambil jam wawancara setelah Rumi selesai Ujian Semester karena sebelum ujian Semester dia lebih banyak tidak masuk sekolah. Pada saat sesi wawancara peneliti menanyakan "kenapa Rumi sering tidak masuk sekolah?" dan dia jawab "karena ngantuk dan malas. Peneliti menyampaikan beberapa motivasi belajar yang menumbuhkan semangat di dalam diri Rumi. Peneliti juga menanyakan beberapa hal seperti "apa cita-cita Rumi?" dan dia mejawab "ingin menjadi tentara". Dia paham kalau ingin menjadi tentara harus rajin belajar dan rajin masuk sekolah. Saat peneliti tanya kembali "kenapa dia suka sekali melamun dan diam di dalam kelas?", dia menjawab "karena saya melamun mainan". Jadi selama ini yang ada dipikiran Rumi adalah mainan. Dia selalu membayangkan mainan yang akan dia mainkan yaitu mainan yang ada di rumahnya.

Peneliti juga menyampaikan beberapa pertanyaan tetapi dia hanya diam walaupun pertanyaan tersebut diulang-ulang oleh peneliti tetap saja dia diam seperti kebingungan menjawab. Rumi juga memiliki alasan kenapa dia tidak ikut main bersama teman-temannya yang lain karena dia lebih sering diganggu dan dicurangi maka dari itu dia lebih baik diam dan melamun di tempat duduknya. Untuk mata pelajaran yang dia sukai saja tidak ada.

Peneliti membuat jadwal ingin menemui orang tua Rumi bertujuan untuk mewawancai. Tetapi susah sekali untuk ditemui karena kedua orangtua Rumi bekerja. Ayahnya bekerja sebagai marketing kaplingan dan ibunya rias pengantin. Akhirnya tepat tanggal 25 Mei 2019 peneliti berkesempatan mewawancarai orang tua Rumi. Peneliti menemui ibunya yang saat itu sedang menjemput Rumi di sekolah nama ibunya Haryati, S.Pd dan ayah Rumi bernama 
Airin Noviyar Nurjani S.Sos. Rumi merupakan anak terakhir dari 4 bersaudara. Kegiatan dia setelah pulang sekolah langsung beristirahat, makan nonton tv dan main. Kedua orang tuanya memang jarang untuk menemani Rumi belajar jadi tidak heran jika Rumi sering tidak mengerjakan tugas sekolah saat di rumah. Rumi saat di rumah merupakan anak yang suka bergerak tetapi susah untuk diajak berkomunikasi. Temannya di rumah hanya sedikit tidak banyak dia cenderung lebih suka menghabiskan waktunya menonton televisi dan bermain sendiri di dalam rumahnya.

Interaksi Rumi terhadap kakakkakaknya ia termasuk adik yang baik tidak mengganggu atau melawan karena dia cenderung diam. Pekerjaan rumah yang diajarkan oleh orang tua Rumi terhadapnya yaitu membiasakan setelah selesai makan harus ditaruh ditempat cucian dan membersihkannya lalu merapikan barang yang telah dihamburnya. Saat peneliti menanyakan hal "kenapa Rumi sering tidak masuk sekolah?", ibunya Rumi menjawab "karena Rumi memiliki sifat yang minder terhadap teman-temannya karena merasa berbeda dengan yang lain, maka dari itu dia terlalu banyak memiliki teman dan berbaur terhadap temannya di kelas.

Harapan kedua orang tua Rumi terhadapnya yaitu agar Rumi bisa menjadi anak yang Sholeh bisa menjadi hafizh AlQur'an. Walaupun orang tuanya Rumi sibuk bekerja dan cenderung sedikit memperhatikan keadaan Rumi, tetapi orang tua Rumi ingin anaknya tumbuh dan berkembang seperti anak pada umumnya. Kerap kali ibu dan ayahnya Rumi memberikan motivasi belajar seperti membahas cita-cita apa yang ingin diraih oleh Rumi, jika ingin mencapai suatu citacita yang tinggi harus rajin belajar tidak boleh malas. Ibunya Rumi sering memberikan motivasi kepadanya setiap kali Rumi tidak mau turun ke sekolah seperti ini "Tetap semangat walaupun sulit, pelan-pelan pasti bisa, karena Rumi anak yang spesial, terus semangat ya nak biar nanti kalau sudah besar bisa jadi tentara, kan Rumi pengen jadi tentara".

\subsubsection{Partisipan III (Anak ADHD Gabungan)}

Partisipan yang ketiga merupakan murid dari petugas tata usaha di sekolah yang sedang peneliti teliti yang bernama Pak Eko Muryadi, S.Pd. Partisipan tersebut berumur 8 tahun dan sekarang duduk di kelas II C yang bernama Apriliansyah Rako Muryadi. Rako merupakan murid yang lucu karena tingkahnya yang unik dan logat dia berbicara yang tidak jelas. Menyebutkan huruf R belum terlalu fasih dan tingkahnya yang kadang usil dan aneh membuat guru yang melihat dia menahan tawa.

Rako memang termasuk murid ADHD dengan gejala ADHD gabungan ringan dengan penjelasan bahwa Rako juga termasuk gejala anak inatensi (susah berkonsentrasi), hyperactivity dan impulsif (melakukan sesuatu hal tanpa didasari pemikiran terlebih dahulu). Dalam kelas Rako susah sekali untuk berkonsentrasi karena dia selalu melamun dan suka melihat ke arah gurunya sewaktu mengerjakan tugas, dia juga termasuk anak hyperactivity yang suka sekali berlari-lari sampai kancing seragamnya lepas, sepatunya lepas, dan suka memanjat pohon yang ada di taman sekolah. Dan Rako merupakan anak impulsif karena dia memiliki rasa yang tidak sabar untuk menunggu giliran, suka mengganggu temannya yang sedang diam tanpa ada alasan dia membuang buku atau benda lainnya. Suka memukul meja seperti sedang memainkan alat musik gendang dan saat proses pembelajaran Rako sering kali tanpa ada perintah dari guru bertepuk tangan dan sambil bernyanyi.

Peneliti mendapatkan kesempatan untuk melakukan observasi terhadap Rako setelah mendapatkan izin oleh guru wali kelas II C tempat Rako belajar. Pada tanggal 15 April 2019 peneliti melakukan pengamatan terhadap Rako saat proses pembelajaran berlangsung. Waktu itu peneliti mengamati tingkah Rako saat akan berbaris memasuki kelas. Memang benar belum masuk kelas baju seragam Rako suka basah karena keringatnya yang bercucuran sehabis belarian padahal itu baru jam pertama yang akan dimulai tetapi pakaiannya sudah kucel dan tidak rapi. Rambut basah karena banyaknya keringat yang keluar.

Saat proses pembelajaran dia merupakan siswa yang masih mempunyai keinginan untuk belajar walaupun lima menit menulis mengerjakn tugas setelah itu lima belas menitnya bermain. Dia juga sosok anak yang sibuk dengan dunianya sendiri, kadang 
ditempat dia duduk Rako bernyanyi sambil bertepuk tangan, lalu ketawa sendiri padahal teman dan gurunya tidak lagi bergurau. Memang sedikit aneh yang Rako lakukan peneliti pun sempat tertawa dan heran. Konsentrasi belajar Rako memang sedikit terganggu kadang guru sedang menjelaskan pelajaran di depan kelas dia melamun melihat ke arah luar kelas. Tetapi jika ditanya oleh guru dia masih bisa menjawab.

Tanpa disadaripun dia suka membuang barang-barang temannya lalu tertawa, suka memukul temannya lalu tertawa seperti kepuasan tersendiri di dalam dirinya ketika usil terhadap temannya tanpa disadari pemikiran dampaknya seperti apa nantinya. Rako juga kerap kali suka mengajak temannya ngobrol di dalam kelas. Ketika guru lama memanggil nama dia, dia langsung gelisah tidak sabar akhirnya pergi menghampiri gurunya. Menurut peneliti hasil dari pengamatan Rako adalah anak yang lucu dengan tingkah kepolosan dia walaupun kadang guru pusing menghadapi tingkahnya.

Hari selasa tanggal 9 Mei 2019 peneliti mengadakan pertemuan dengan wali kelas II C yang bernama ibu Daul untuk meminta waktunya sebentar untuk diwawancarai mengenai hal-hal yang berhubungan dengan Rako, saat berada di dalam kelas baik tingkah laku dan prestasi belajarnya. Dari hasil paparan yang telah disampaikan. Dia memang anak yang suka bermain saat mengerjakan tugas suka mondar-mandir di dalam kelas sambil mengganggu temannya. Kalau temannya tidak menghiraukan, dia suka mencari perhatian terhadap guru dan temannya seperti pukul-pukul meja, tepuk-tepuk tangan sambil bernyanyi. dari 27 siswa Rako adalah siswa yang memiliki tingkah hyperactivity. Sebetulnya Rako lumayan pintar hanya saja dia suka bermain dan menganggu temantemannya. Dalam hal menerima pelajaran kondisi Rako sesuai dengan suasana hatinya kadang jika Moodnya baik cepat selesai mengerjakan tugas dan jika moodnya buruk dari awal mulai pelajaran sampai selesai pelajaran dia tidak akan mau menulis atau mengerjakan tugas.

Perilaku Rako terhadap gurunya termasuk anak yang baik, tidak pernah melawan. Dia anak yang lucu dengan sikap polosnya jika ada hal yang ingin ditanyakan kepada guru dia hanya senyam-senyum seperti minta perhatian dengan gaya berbicara logat yang tidak jelas membuat guru kadang tertawa. Kemampuan akademik Rako termasuk baik karena sudah lancar membaca dan PR selalu di kerjakan hanya saja tulisan dia yang kurang rapi. Bu Daul pun sering mengatasi agar dia bisa menulis rapi seperti duduk di samping beliau sekitar 10 menit agar menulisnya tidak terburu-buru, tetapi jika bu Daul meninggalkannya dia akan mulai melakukan ulahnya kembali seperti menulis tidak rapi karena terburu-buru, mondar-mandir mengganggu temannya, tepuk-tepuk tangan dan tepuk meja.

Kendalanya yang dialami bu Daul yaitu ketika dimana ada saat-saatnya susah untuk diatur dan saatnya dia nurut. Kalau Rako mudah untuk diatur bu Daul merasa senang tapi kalau disaat Rako mulai susah untuk diatur bisa menyebabkan sakit kepala. Cara mengatasi rako saat tidak bisa diatasi yang sering bu Daul lakukan dengan merayu dan duduk di sampingnya. Karena dia sosok anak yang suka dirayu dan dibujuk dengan perhatian.

$\mathrm{Bu}$ Daul sebagai wali kelas sering memberikan motivasi belajar seperti ancaman jika dia tidak mau nurut dan tidak mau menulis nanti akan tinggal kelas. Dalam kondisi Rako seperti ini sangat penting menumbuhkan motivasi dan pendekatan terhadap dirinya. Perkembangan dia saat di kelas satu mengalami kenaikan yang lumayan. Pada saat masih duduk di kelas satu dia hanya tahunya bertanya tentang "bu kapan istirahat?" dan "bu kapan pulang?" susah menulis dan belum bisa membaca.

Peneliti mengalami kendala saat akan mewawancarai orang tua Rako, karena wali kelas Rako tidak mengizinkan peneliti melakukan sesi wawancara terhadap orang tua Rako dikarenakan orang tua Rako pernah bekerja sebagai petugas tata usah di sekolah tersebut. Ditakutkan orang tua Rako tersinggung atau tidak enak hati mengenai wawancara yang akan dilakukan oleh peneliti tentang anak ADHD. Maka dari itu peneliti tidak memiliki gambaran bagaimana kondisi keadaan Rako sehari-harinya saat di rumah. Peneliti melakukan sesi wawancara kepada guru PJOK dan guru agama Rako mengenai perilakunya.

Hasilnya sama saja seperti yang telah disampaikan oleh guru wali kelas Rako. Pada partisipan ketiga ini tidak ada data penunjang 
dari orang tua Rako peneliti menggalih informasi mengenai Rako dari wali kelas, guru PJOK dan guru Agama. Ketika peneliti melakukan wawacara terhadap teman Rako untuk menyampaikan pendapatnya mengenai bagaimana perilaku Rako. Mereka hanya menjawab "Rako usil", "Rako suka menganggu". Dapat diartikan memang benar adanya Rako anak yang usil suka menganggu temannya karena dia suka mencari perhatian.

Pada tanggal 14 Mei 2019 hari selasa peneliti akhirnya berkesempatan bertemu dengan Rako. Karena setiap ingin ditemui Rako selalu tidak masuk sekolah. Pada saat akan diwawancarai susah sekali membujuk Rako karena anaknya pemalu dan tidak mau. Dengan berbagai rayuan akhirnya Rako bersedia diwawancarai. Setiap peneliti bertanya dia hanya tersenyum. Sampai akhirnya peneliti bingung bagaimana caranya agar dia mau menjawab pertanyaan, karena dia hanya tersenyum dan menganggukkan kepalanya. Saat peneliti bertanya "apa citacita Rako?" dia menjawab "mobil tebakaya". Peneliti bingung apa yang dibicarakannya tapi juga lucu karena tingkah polosnya. Setelah peneliti mendengarkan baik-baik maksud Rako ingin menjadi mobil kebakaran. Saat ditanya "kenapa Rako suka lambat mengerjakan tugas dari ibu guru?", dia hanya tersenyum. Dari pemaparan yang telah dia sampaikan mengenai kegiatannya di rumah. Dia juga rajin mengaji dan membantu orang tuanya jika libur sekolah seperti menyiram tanaman.

\subsubsection{Partisipan IV ( Anak ADHD Hyperactivity)}

Peneliti menemukan partisipan

ADHD yang keempat dengan gejala anak hyperactivity. Sama dengan partisipan kesatu yang memiliki gejala anak ADHD hyperactivity bedanya hanya terdapat pada tingkatan kelas. Untuk partisipan yang keempat umurnya lebih tua yaitu 10 tahun yang sedang duduk di kelas IV A yang bernama Pedrosa. Pedrosa merupakan anak yang super sekali tidak bisa diam di dalam kelas. Dia suka sekali merobek-robek kertas untuk dijadikan pesawat terbang. Dia juga anak yang suka menganggu temannya dan usil sekali tetapi jika diganggu balik dia akan marah.

Seragam yang dikenakannya pada hari senin sudah sangat kotor dan lusuh penyebabnya dia suka sekali guling-guling dilantai, lari-lari sampai pakaiannya basah, suka manjat tiang bendera, meluk tembok. Sehingga orang yang melihatnya akan merasa capek tetapi dia tidak memiliki rasa capek ataupun letih.Dari kehidupannya Pedrosa merupakan anak yang kaya sehingga sering sekali membelikan jajan terhadap temantemannya pada saat dia dijauhi oleh temannya. Itulah siasat Pedrosa jika dia mulai dijauhi oleh temannya terhadap gurupun dia sosok anak yang tidak pelit. Walaupun dia memiliki gerakan yang berlebihan tetapi dalam bersosialisasi dan berinteraksi terhadap guru dan temannya dia termasuk anak yang baik.

Dalam potensi akademiknya Pedrosa bukan termasuk anak yang dibawah karena nilai-nilainya cukup baik. Setiap ujian dia juga mendapatkan nilai di atas KKM. Hanya saja seperti kerapian dan perlengkapan alat tulis kurang diperhatikan oleh orang tuanya. Sering tidak membawa buku atau alat tulis hampir setiap hari dia membeli buku dan bolpoin ke koperasi sekolah.

Pada tanggal 16 April 2019 peneliti menentukkan hari selasa untuk melakukan observasi terhadap Pedrosa. Pada saat itu peneliti melakukan pengamatan yang cukup lama di dalam kelas untuk mencari tahu kebiasaan Pedrosa saat belajar. Karena pada saat PPL agustus tahun kemaren peneliti tidak sempat untuk mengajar di kelasnya. Sehingga peneliti melakukan observasi lebih lama dari partisipan yang lainnya. Pada saat proses pembelajaran Pedrosa duduk dibarisan ketiga dari depan.

Waktu masuk kelas peneliti sedikit kaget karena melihat dia pake sendal jepit dan baju sedikit keluar dan kotor. Saat itu wali kelas Pedrosa sedang menjelaskan pelajaran sedangkan dia sibuk merobek kertas untuk dijadikan pesawat terbang. Berkali-kali peneliti amati kertas dirobeknya untuk dijadikan mainan. Saat sudah ditegur oleh gurunya dia akan menyembunyikan mainannya dan mulai menulis tugas yang telah diberikan. Lalu tidak lama dia kembali bermain setelah bosan membuat pesawat terbang dia menggambar dibuku tulis matematikanya padahal saat itu sedang berlangsung mata pelajaran matematika bukan pelajaran SBdP.

Bukan hanya suka mainan di dalam kelas tapi dia juga mempunyai seribu alasan agar bisa keluar masuk kelas seperti alasan 
membeli bolpoin atau buku, alasan membuang sampah, alasan pergi ke wc. Pedrosa memang anak yang tidak bisa duduk dengan tenang dan fokus untuk saat belajar. Tetapi, jika dia sudah mulai dimarahi oleh guru dan diancam untuk keluar dari kelas tidak boleh mengikuti pelajaran dia merasa takut dan langsung mengerjakan tugasnya. Jika guru sudah lengah tidak memperhatikan dia, dia akan bertingkah kembali. Dia akan mengganggu temannya, seperti memukul atau mengajak bercerita.

Hari rabu tanggal 10 Mei peneliti memutuskan untuk menemui wali kelas Pedrosa untuk melakukan wawancara mengenai hal-hal yang bersangkutan dengan Pedrosa saat berada di sekolah. Pada saat peneliti melakukan wawancara terhadap wali kelas IV A yang bernama ibu Yanti. Pada saat peneliti melakukan sesi pertanyaan tentang anak ADHD dan ternyata bu Yanti belum mengetahui apa itu ADHD dan hanya tahu kalau anak seperti pedrosa itu kebanyakan gerak dan tidak bisa diam. Setelah peneliti menjelaskan akhirnya bu Yanti lebih paham tentang tipe-tipe anak ADHD.

Perilaku yang sering Pedrosa lakukan saat di kelas suka sekali kesana kemari ketempat duduk temannya. Duduk suka berpindah-pindah lebih tepatnya suka mengambil tempat duduk temannya, bukubuku dan alat tulis suka berantakan, jika ada barangnya yang jatuh tidak akan diambilnya dan dibiarkan begitu saja sampai pulang sekolah. Setiap hari selalu ada saja alat tulisnya yang hilang dan membelinya di koperasi karena oranng tuanya memberi uang jajan banyak sehingga dia foya-foya saat di sekolah. Saat guru duduk dia sering merangkak bersembunyi di kolong meja dia pikir bu Yanti tidak memperhatikannya saat dia melakukan hal-hal yang aneh di dalam kelas. Padahal Pedrosa anak yang pintar walaupun tulisaanya tidak rapi tapi dia tipe anak yang mudah menangkap pelajaran yang didengar lalu diingat. Bu Yanti hanya bisa geleng-geleng kepala saat melihat tingkah laku Pedrosa karena sudah beribu teguran dan teriakan tetap saja dia akan bertingkah berlebihan.

$\mathrm{Bu}$ Yanti sampai pusing padahal masih hari senin tapi bajunya sudah kotor, lusuh, dan bau. Suka ingusan seperti tidak dirawat oleh kedua orang tuanya padahal
Pedrosa dari keluarga yang kaya. Suka melepas sepatu dan berlari-lari akhirnya sampai pernah kakinya kena kaca. Interaksi Pedrosa terhadap bu Yanti sosok anak yang baik karena tidak pernah membantah dan melawan. Dia akan nurut jika apa yang bu Yanti suruh kepadanya seperti nulis satu kalimat tapi sebanyak dua lembar buku karena dia selalu menulis asal-asalan sehingga dibaca tidak jelas dan berantakan.

Tanggal 13 Mei hari senin peneliti melakukan pertemuan bersama Pedrosa anak terakhir dari 3 bersaudara yang akan peneliti wawancarai. Saat berangkat dan pulang sekolah Pedrosa selalu diantar dan dijemput oleh karyawan ayahnya. Belajarpun di rumah dia sendiri tidak didampingi oleh orang tuanya. Padahal orang tuanya ada di rumah ibunya hanya sebagai ibu rumah tangga dan ayahnya punya usaha besi tua dan bengkel mobil. Dia anak yang dimanja tetapi tidak diperhatikan dalam masalah sekolahnya. Apa yang diinginkan oleh Pedrosa selalu dituruti bahkan saku sekolahnya saja sampai seratus ribu bahkan lebih, walaupun pernah tidak diberi uang saku sama sekali karena dia melakukan kesalahan. Pulang sekolah bukannya seperti anak lainnya seperti makan lalu istirahat sedangkan dia sampai di rumah langsung bermain kembali. Penampilan pergi ke sekolahpun tidak diperhatikan oleh kedua orang tuanya. Pedrosa memakai kalung seperti rantai, baju acak-acakan warnanya sudah bukan putih lagi menjadi warna kuning, celana robek karena suka gulingguling di lantai.

Peneliti melakukan sesi pertanyaan seperti “apa cita-cita Pedrosa?" dia menjawab "ingin menjadi pilot". Saat melakukan berbincangan dengan Pedrosa, dia paham apa yang kita tanyakan tetapi selalu lama untuk menjawabnya. Saat ditanya "emang ga dimarah kalau pulang sekolah bajunya kotor seperti ini, lalu dia menjawab "memang sudah kotor dari rumh". Pedrosa memang anak yang kekurangan perhatian dari kedua orang tuanya, hidupnya memang serba ada tetapi dia kurang perhatian dan pengawasan dari orang tuanya wajar saja dia suka cari perhatian kepada guru dan teman-temannya. Untuk sesi wawancara Pedrosa tidak terlalu banyak yang didapatkan karena dia terlalu lama menjawab sehingga waktunya tidak cukup. Untuk wawancara orang tua Pedrosa 
tidak ada dikarenakan tidak adanya persetujuan dari pihak wali kelas Pedrosa. Mengetahui seperti apa sosok kedua orang tua Pedrosa ditakutkan akan tersinggung dan akan menolak bahwa Pedrosa termasuk anak ADHD tipe hyperactivity.

\subsubsection{Partisipan $V$ (Anak ADHD Inatensi)}

Partisipan terakhir pada penelitian ini bernama Mikael Jibril Angelo yang sering dipanggil dengan sebutan Miki. Sudah berusia 10 tahun duduk di kelas IV A bersama Pedrosa partisipan keempat. Miki merupakan kakak dari Rumi partisipan kedua dengan gejala yang sama yaitu inatensi anak ADHD. Miki memiliki kebiasaan yang sama seperti adiknya si Rumi hanya bedanya Miki sudah bisa membaca dan lebih paham jika diajak berkomunikasi. Miki merupakan sosok anak yang pendiam tidak banyak bicara, dia anak yang tidak pernah menganggu temannya tapi temannyalah yang suka menganggu dia. Jika dia diganggu dia akan berteriak hanya itu senjata untuk melindungi dirinya. Di dalam kelaspun dia suka diam, anak yang tidak ceria pada umumnya. Jika anak lainnya akan mudah tertawa tapi sebaliknya dengan Miki yang memilih muka selalu datar tanpa ekspresi. Tapi dalam sikap sopan santun dia termasuk anak yang cukup baik karena sopan dan patuh kepada gurunya.

Tepat hari rabu tanggal 17 April 2019 peneliti melakukan observasi di dalam kelasnya Miki. Peneliti mengamati apa saja yang ia lakukan jika saat proses pembelajaran. Yang peneliti dapatkan bahwa benar adanya kalau Miki seperti adiknya tidak banyak gerak dan tidak banyak bicara. Jika dia tidak dipaksa bicara maka dia tidak akan berbicara. Miki lebih baik diam dan bengong saat di salam kelas, jika ada temannya yang bermain dia hanya diam. Dia seperti anak yang dijauhi atau dimusuhi oleh teman-temannya padahal tidak seperti itu. Tingkahnya yang diam membuat temannya malas untuk mengajak dia mengobrol dan belajar bersama. Saat ditanya oleh guru tentang pelajaran saja dia tidak menjawab hanya diam, jika guru sudah mulai sedikit emosi dia akan menjawab tetapi dengan nada suara yang sangat pelan mungkin hanya dirinya sendiri yang bisa mendengarkan suarnya. Seperti itulah Miki jika sedang di dalam kelas. Hanya diam, bengong dan melamun sesekali. Tidak pernah mencoba bertanya kepada guru atau menjawab.

Hari kamis siang pada tanggal 9 Mei, peneliti berkesempatan bertemu dengan Miki untuk melakukan wawancara. Pada saat wawancara jawaban Miki kebanyakan biasa aja dan sangat singkat. Tetapi, dia mudah paham apa yang peneliti tanyakan. Walaupun Miki saat diwawancarai seperti anak yang melongo dan bengong tetapi dia ada jiwa semangat untuk menjawab setiap pertanyaan walaupun jawabannya itu-itu saja. Saat peneliti bertanya "kenapa suka diam dan melongo atau bengong di dalam kelas?" jawabannya selalu "gak tahu". Walaupun dia anak yang pendiam, suka melamun dan tidak ada ekspresi pada wajahnya, tetapi dia masih bisa marah jika merasa dirinya terganggu. Memang jika kita bertemu dengan Miki akan merasa lucu melihat dia karena muka polosnya yang tidak ada ekspresinya yang selalu datar seperti lagi menimpa masalah yang sangat besar.

Miki mempunyai cita-cita yang amat baik yaitu ingin menjadi tentara. Maka dari itu peneliti memberikan sedikit arahan dan nasihat terhadap dia. Bahwa sosok tentara harus kuat dan tegas tidak boleh suka bengong sendirian dan melamun. Karena tentara harus kuat dan banyak tersenyum. Kalau diajak berbicara mengeluarkan suara yang lantang bukan suara bisik-bisik yang bisa mendengar hanya diri sendiri. Walaupun peneliti berusaha melucu dihadapan dia tetap saja ekspresinya datar dan dia tidak sema sekali senyum ataupun tertawa.

Setelah selasai mewawancarai Rumi, tepat hari rabu tanggal 10 mei peneliti melakukan wawancara bersama guru wali kelas Miki. Bu Yanti menceritakan kebiasaan Rumi ketika di dalam kelas. Miki selalu tidak mengerjakan PR jika ditanya selalu alasannya lupa tidak ada yang lain. Datang ke sekolah selalu terlambat dan alasannya selalu sama tidak ada yang mengantar. Dan jika ditanya sama seperti yang peneliti alami, Miki selalu tidak menjawab pertanyaan dan bengong dengan muka datarnya. Dalam mengatasinya $\mathrm{Bu}$ Yanti tidak terlalu banyak memberikan perhatian penuh karena Miki masih bisa mau menulis dan membaca hanya saja dia suka bengong dan melamun di dalam kelas.

Kali ini peneliti mendapatkan izin untuk mewawancari orang tua Miki karena sekalian mewawancarai tentang kebiasaan 
yang dilakukan oleh Rumi (partisipan II) saat berada di rumah. Lalu peneliti melanjutkan wawancara kembali menanyai tentang Miki saat di rumah. Tepat tanggal 25 mei hari rabu berlokasi di sekolah pada saat sedang menjemput Miki. Kebiasaan yang dilakukan oleh Miki jika setelah dari sekolah yaitu istirahat lalu main bersama teman-teman di dekat rumahnya. Saat di rumahpun kedua orang tua Miki mengaku tidak pernah melakukan bimbingan belajar dimana orangtua menemani anaknya untuk belajar dan membantu mengerjakan PR. Bahkan untuk mengecek ada PR atau tidaknya hari ini sama sekali tidak pernah. Maklum saja Miki sering tidak mengerjakan PR. di rumah Miki juga anak yang tidak rajin belajar, dia lebih suka bermain dan menonton televisi selain itu dia sangat jarang membantu pekerjaan di rumah. Tetapi dia merupakan anak yang patuh karena setiap apa yang dilarang oleh kedua orang tuanya, dia selalu mematuhinya.

Kebiasan yang orang tua Miki berikan tugas tehadapnya yaitu sebagai keamanan rumah bertugas mengecek pintu ketika malam sudah dikunci atau belum dan tugasnya membakar sampah. Di rumah Miki anak yang sedikit banyak gerak tapi tidak banyak bicaranya. Sangat berbeda saat di sekolah Miki cenderung anak yang sedikit mempunyai teman tapi saat di rumah dia memiliki banyak teman maka dari itu dia lebih suka main di luar rumah ketimbang main di dalam rumah. Tidak seperti adiknya yang suka berdiam di rumah ketimbang harus keluar rumah. Miki termasuk anak ketiga dari empat bersaudara, sikap dia terhadap saudaraanya cukup baik tapi suka ngomel kalau dia merasa terganggu atau kakak dan adiknya melakukan kesalahan.

Harapan kedua orang tua Miki terhadap dia yaitu menjadi anak sholeh dan baik kepada siapapun dan dimanapun. Pemberian motivasi belajar yang mereka berikan untuk Miki seperti meyakinkan Miki jika memiliki suatu impian yang tinggi harus yakin dan bisa meraihnya. Miki anak yang sangat menyukai semua hal yang berhubungan dengan Rusia, mempunyai mimpi bisa kuliah di Rusia. Dan orang tua Miki memberikan motivasi belajar seperti nasehat "Kalau mempunyai impian besar harus semangat rajin belajarnya, rajin berdoa. Tidak ada yang mustahil kalau Allah SWT sudah menghendaki-Nya". Seperti itulah yang orang tua Miki memberikan motivasi belajar bahwa apapun bisa tercapai kalau kita rajin belajar dan berdoa.

\subsection{Pembahasan Penelitian}

Berdasarkan hasil penelitian ditemukan bahwa latar belakang anak ADHD dengan tipe yang berbeda mempunyai ciri dan kemampuan yang tidak sama. Tingkat perhatian orang tua juga mempengaruhi motivasi belajar dan perilaku sehari-harinya. Terdapat anak ADHD dengan tipe Inatensi cirinya memang terkesan diam tidak banyak tingkah tetapi lama untuk menerima pelajaran dan susah untuk diajak berkomunikasi, sebaliknya dengan anak hyperactivity anak yang cenderung tidak bisa diam dan membuat keributan tetapi masih mudah untuk menerima pelajaran dan bisa diajak untuk berkomunikasi. Beda dengan anak tipe ADHD gabungan anak tersebut cenderung susah untuk menerima pelajaran, susah untuk diajak berkomunikasi serta sering menimbulkan keributan karena tingkahnya yang tidak bisa diam berlarian kesan kemari dan suka mengganggu temannya.

Bahwasannya semakin tinggi tingkat perhatian orang tuanya semakin tinggi juga pengaruh pertumbuhan dan perkembangan anaknya. Jika orang tua memiliki motivasi yang tinggi dalam proses pembelajaran si anak maka tinggi pula motivasi belajar yang tumbuh dalam anak tersebut. Hal ini sejalan dengan PAI (2016) bahwa orang tua memegang peranan penting dan amat berpengaruh terhadap pendidikan anaknya. Motivasinya sangat penting dan dibutuhkan pada saat proses belajar, yang dimana semakin adanya motivasi maka semakin banyak hal yang dilakukannya. Terutama dalam hal belajar karena motivasi merupakan suatu dorongan untuk mengerjakan sesuatu hal yang membawa dampak positif bagi anak tersebut.

Adapun dalam hal ini menurut Sardiman (2014) motivasi ialah suatu penggerak dari dalam hati seseorang untuk melakukan atau mencapai suatu tujuan. Motivasi belajar biasanya disebabkan oleh faktor internal yang berasal dari dalam diri dan faktor eksternal yang berasal dari luar. Adapun hasil dari penelitian terdapat beberapa siswa yang memiliki motivasi belajar faktor eksternal yang didapatkan dari 
perhatian khusus oragtua dan gurunya. Orang tua yang senantiasa sabar memberikan perhatian yang khusus kepada anaknya maka anak tersebut akan memiliki kemauan untuk belajar walau dengan cara dipuji terlebih dahulu dan ditemani saat proses belajar membuat anak semangat untuk belajar. Hal ini sejalan dengan Syah (2014) bahwasanya seorang siswa yang berinteligensi tinggi (faktor internal) dan mendapat dorongan positif dari orang tuanya (Faktor eksternal), mungkin akan memilih pendekatan belajar yang lebih mementingkan kualitas hasil belajar.

Berdasarkan hasil observasi dan wawancara terhadap partisipan Fatir Mengalami hyperactivity ringan. Walaupun gejalanya hyperactivity ringan tetap saja berpengaruh pada perilaku Fatir di sekolah, interaksinya, perubahan emosi, dan motivasi belajarnya. Selama proses belajar berlangsung Fatir menunjukkan perilaku yang berbeda dengan teman-temannya. Perilakunya yang suka usil terhadap temannya tetapi jika diusilin balik oleh temannya tidak mau. Pengalaman peneliti saat melakukan observasi dan wawancara terhadap Fatir. Ia menunjukkan sikap yang tidak bisa diam seperti suka menggoyangkan kaki dan tangganya, suka sekali keluar masuk kelas, suka memainkan benda yang ada disekitarnya, suka mengusili temannya, suka ngajak ngobrol temannya, suka berjalan-jalan dari tempat duduk temannya ke temannya yang lain.

Kelebihan yang dimiliki Fatir yaitu masih bisa menangkap pelajaran walaupun harus secara khusus seperti ada jam sendiri untuk Fatir agar cepat mengerjakan tugas. Fatir termasuk anak yang pintar walaupun dia hyperactivity dia selalu masuk peringkat 10 besar. Dan jika ditanyai tentang soal pelajaran masih bisa menjawab hanya saja dia lama mengerjakan tugas karena tidak bisa diam. Kesimpulan peneliti terhadap Fatir didukung oleh pernyataan guru kelas Fatir. Pada saat peneliti melakukan wawancara terhadap guru Fatir. Beliau menjelaskan bahwa Fatir memang anak yang banyak bergerak susah sekali untuk diam, usil terhadap temannya, suka sekali keluar masuk kelas alasannya meraut pensil atau buang air kecil, tidak bisa menyelesaikan tugas dengan tepat waktu selalu lama dan paling terakhir. Tetapi Fatir termasuk anak yang mudah menangkap pelajaran dan lumayan pintar di dalam kelas.

Hasil dari observasi dan wawancara dari berbagai narasumber dapat diketahui bahwa anak inatensi seperti Rumi harus diberikan perhatian yang khusus dan perlakuan yang lebih. Karena anak tipe seperti itu tidak dapat diperlakukan dengan tindakan keras atau melakukan paksaan terhadapnya untuk mengerjakan sesuatu hal yang tidak ia sukai. Rumi adalah anak yang susah sekali berkomunikasi hal tersebutlah yang menyebabkan dia tidak memiliki teman dan merasa malu dengan keadaan dirinya. Dia berbeda dari anak yang lain yang dapat dengan mudah berkonsentrasi dan berpikir sedangkan Rumi anak yang sangat sulit untuk berkonsentrasi dia hanya bisa melamun dan diam.

Walaupun kondisi Rumi seperti itu wali kelasnya tidak patah semangat untuk tetap mendidik dan mengajarkan Rumi agar cepat bisa menghapal huruf abjad dan memberikan perlakuan yang khusus selalu dibimbing setelah pulang sekolah. Ibu Sri menyempatkan waktu untuk melatih Rumi agar cepat membaca dan berusaha terusmenerus diajak berkomunikasi agar lancar menjawab dan tidak lupa selalu memberikan motivasi belajar di dalam diri Rumi. Peranan orang tuapun penting bagi tumbuh kembangnya Rumi. Walaupun kedua orang tuanya sibuk berkerja sampai kadang lupa menjemput Rumi pulang sekolah dan jarang menemani Rumi mengerjakan PR di Rumah. Tetapi, kedua orang tuanya selalu memberikan motivasi belajar terhadap Rumi agar tidak pantang menyerah dengan kondisinya yang seperti saat ini.

Hasil dari observasi dan wawancara dengan beberapa narasumber peneliti dapat menjelaskan pokok permasalahan yang dialami oleh Rako anak yang termasuk golongan ADHD dengan tipe gabungan. Dimana konsentrasi Rako tidak terkontrol saat proses pembelajaran dan saat diajak berkomunikasi Rako hanya bisa mengangguk. Dalam konsentrasi belajar dia memiliki tingkat suasana hati yang tidak menentu, kadang suasana hatinya baik dia akan rajin dan saat hatinya buruk dia benarbenar tidak mau untuk menulis bahkan mengeluarkan alat tulis dan bukupun dia tidak mau. Tipe anak seperti Rako tidak bisa diberikan teguran yang keras atau paksaan. 
Rako harus diperlakukan dengan baik, diajak berkomunikasi dengan baik, ditanya apa keinginan dia.

Anak ADHD seperti Rako harus sering dipuji apapun yang dia kerjakan. Karena dia sosok anak yang suka dipuji untuk membangkitkan semangat belajarnya. Seberapa salah yang dilakukan harus diberikan teguran tapi dengan cara yang baik seperti berbicara pelan-pelan, karena Rako termasuk anak yang susah diajak berkomunikasi harus berulang kali menyampaikan sesuatu kepadanya agar dia paham dan mengerti. Untuk berbicara saja Rako mengalami kesulitan karena susah mengucapkan huruf $\mathrm{R}$ dan logat berbicara dia yang sedikit tidak jelas sehingga orang yang berbicara dengan Rako harus mendengarkan betul-betul apa yang ia katakan.

Rako merupakan sosok murid yang mempunyai ketegori hyperactivity yang sangat tinggi dan bisa dikatakan bahwa Rako merupakan anak hyperactivity diantara teman-temannya dari 27 siswa/siswi. Rako memang suka sekali berlari-lari sudah dijelaskan sebelumnya bahwa sebelum masuk pelajaran pertama dimulai dia sudah berlarilari sampai seragamnya basah kuyup garagara berkeringat dan kancing baju lepas. Pelajaran belum dimulai tapi pakaian seragamnya sudah lusuh, kucel dan bau keringat. Di dalam kelaspun dia tetap tidak bisa diam. Saat temannya sibuk mengerjakan tugas dia malah sibuk mondar-mandir jalan kesan-kesini menghampiri temannya. Bukan hanya mondar-mandir tapi dia juga suka mengganggu temannya seperti mencari teman agar tidak mengerjakan tugas sama-sama bersama dia.

Jika sudah seperti itu temannya selalu melapor ke guru dan Rako mendapatkan teguran lalu dia duduk tetapi, belum sampai lima menit dia membuat ulang lagi mengajak temannya mengobrol. Jika temannya tidak menghiraukan dia memukulmukul meja atau bertepuk tangan yang menyebabkan terganggunya keadaan kelas menjadi tidak kondusif karena ulah si Rako. Upaya yang dilakukan guru ketika Rako seperti itu yaitu menyuruh Rako duduk di meja guru kadang agar dia diam atau mendapatkan teguran jika tidak mengerjakan tugas akan di suruh keluar, itu hanya ancamana agar Rako takut dan jera tetapi pada kenyataanya tetap saja dia tidak bisa diam.

Gejala Rako yang terakhir yaitu impulsif diartikan bahwa gejala ini timbul dalam diri Rako karena suka melakukan halhal yang tidak didasari pemikiran terlebih dahulu. Seperti contohnya dia suka sekali usil terhadap temannya. Barang milik temannya tanpa didasari apapun tiba-tiba dibuang, tibatiba mukul temannya tapi jika dibalas temannya dia tidak mau. Mempunyai sifat tidak bisa sabar jika ada antrian mengambil buku ke depan dia tidak sabar nama dia dipanggil, tidak sabar ingin cepat istirahat dan pulang ke rumah. Cara mengatasi hal tersebut guru hanya bisa menegur dan memberi tahu Rako bahwa perbuatan seperti itu tidak boleh nanti bisa dijauhi temannya. Setiap teguran yang disampaikan oleh guru hanya angan-angan saja bagi Rako karena tidak pernah masuk ke telinga untuk didengarkan baik-baik.

Pokok permasalah yang dialami oleh Pedrosa sehingga dia menjadi salah satu anak ADHD gejala hyperactivity yaitu kurangnya perhatian dari kedua orang tuanya. Dia anak yang sangat banyak gerak, tidak kenal lelah. Selalu suka mencari perhatian temannya bahkan gurunya. Dia cenderung anak yang suka kalo kita dekati, seperti kita ajak mengobrol. Memang terlihat kondisi Pedrosa seperti tidak terurus walaupun apa yang dia inginkan selalu diberikan oleh kedua orang tuanya. Bahkan PR jarang dikerjakan alasan dia kecapean bermain.

Keseharian dia hanyalah bermain di sekolah bermain dan di rumah bermain kembali. Jadi, tidak ada waktu dia untuk belajar. Sangat disayangkan padahal dia anak yang cukup pandai karena kurangnya perhatian dari orangtua yang terlalu sibuk mencari uang sehingga anaknya tidak terurus. Pakaian berangkat ke rumah selalu kotor, bau dan jorok. Padahal dia dari keluarga yang terpandang kaya dalam finansial. Wali kelasnya sering merasa kasihan melihat Pedrosa, maka dari itu ibu gurunya tidak terlalu memperlakukan keras kepada Pedrosa karena merasa kasihan melihat anak yang kurang perhatian saat di rumah. Kadang gurunya Pedrosa berinisiatif untuk membimbing dia mengerjakan tugas, melakukan suatu pendekatan terhadapnya agar semangat belajarnya. Anak seperti Pedrosa tidak bisa untuk diperlakukan 
dengan keras atau terlalu sering dimarahi. Anak seperti itu jika dimarahi terus menerus akan berdampak pada jiwanya dan pikirannya. Maka dari itu guru wali kelasnya selalu memuji usaha yang telah Pedrosa lakukan. Anak seperti Pedrosa jika mendapatkan pujian akan merasa termotivasi sehingga belajarnya akan menjadi lebih rajin. Dan merasakan kesenangan di dalam dirinya. Dia akan berpikir jika melakukan sesuatu yang benar akan mendapatkan pujian dari guruku itulah bentuk motivasi yang tepat untuk anak seeperti Pedrosa. Permasalahan yang di alami Miki tidak terlalu sulit, hanya saja tingkah Miki yang sedikit aneh. Menyebabkan seperti beda dari temantemannya yang lain. Saat Miki diajak berbicara dmasih dia masih dapat merespon dan nyambung jika menjawab pertanyaan walaupun dengan raut muka yang selalu aneh, dan jawabannya itu-itu saja tidak ada yang lain. Dia hanya kurang perhatian dari pihak orang tuanya sehingga tugas-tugas sekolah sering terabaikan. Padahal anak seperti Miki masih butuh pengawasan dan perhatian penuh. Harus dibimbing karena dia tipe anak yang belum mandiri dalam keseluruhan. Harus diingatkan dan diarahan. Kerana dia tipe anak inatensi yang suka diam dan susah untuk berkonsentrasi.

\section{KESIMPULAN}

Berdasarkan hasil penelitian dan pembahasan pada bab sebelumnya, maka dapat disimpulkan bahwa motivasi belajar ADHD cenderung minim. Dikarenakan anak ADHD merupakan anak yang sedikit berbeda dari segi kemampuan dan tingkah lakunya. Maka dari itu, motivasi belajar harus ditumbuhkan di dalam diri siswa ADHD, peran penting orang tua dan gurulah yang bisa mendidik dan mengembangkan potensi belajar di dalam diri anak ADHD. Karena siswa dengan gejala ADHD tersebut harus mendapatkan penanganan yang khusus tidak bisa sembarangan dibiarkan dan diperlakukan kasar. Siswa dengan gejala ADHD cenderung suka dipuji dan diperhatikan. Anak ADHD mempunyai tiga gejala yaitu hyperactivity siswa yang cenderung tidak bisa diam atau banyak gerak yang melebihi kapasitas gerakan anak pada umumnya, inatensi yaitu siswa ADHD yang susah memusatkan suatu perhatian seperti sulit untuk diajak berkomunikasi karena cenderung bengong dan melamun dan tidak pandai dalam bersosialisasi terhadap teman maupun orang disekitarnya terakhir gejala impulsif yaitu siswa ADHD yang suka melakukan suatu hal tanpa didasari pemikiran terlebih dahulu seperti apapun yang membuat dia senang akan dilakukan tanpa tahu resikonya.

\section{DAFTAR PUSTAKA}

Afisa, D. (2018). Meningkatkan Konsentrasi Belajar Siswa ADHD dengan Menggunakan Teknik Token Economic. Universitas Negeri Jakarta.

Afrizal. (2016). Metode Penelitian Kualitatif. Depok: RajaGrafindo Persada.

Ahmad, B. (2015). Peningkatan Motivasi Belajar Siswa Melalui Konseling Klasikal. Jakarta: CV. Abe Kreatifindo. Ahmadi, R. (2014). Metodologi Penelitian Kualitatif. Yogyakarta: Ar-Ruzz Media.

Baihaqi, M., \& Sugiarmin. (2014). Memahami dan Membantu Anak $A D H D$. Bandung: PT Refika Aditama.

Dayana, I., \& Marbun, J. (2018). Motivasi Kehidupan. Jakarta: Guepedia.

Elsjelyn, E. R. (2014). English Made Easy. Jakarta: Kesaint Blanc.

Fathurrohman, M., \& Sulistyorini. (2018). Belajar \& Pembelajaran. Yogyakarta: Kalimedia.

Jaya, A. K. (2016). Pola Bimbingan Dalam Menumbuhkan Bakat Anak ADHD (Attention Deficit Hyoeractivity Disorder) di Lembaga Pemberdayaan Perempuan dan Anak pinggiran (PPAP) Seroja Surakarta. Institut Agama islam Negeri Surakarta.

Kewley, G., \& Latham, P. (2010). 100 Ide Membimbing Anak ADHD. Indonesia: Erlangga.

Kurniasari, B. R. (2015). Layanan Guru Pada Siswa Attention Deficit Hyoeractivity Disorder (ADHD) di Kelas V SD Negeri 1 Sedayu Kecamatan Sedayu Kabupaten Bantul. Biomass Chem Eng. Universitas Negeri Malang.

Murtie, A. (2016). Ensikklopedi Anak Berkebutuhan Khusus. Jogjakarta: Katalog Dalam Terbitan.

P, D. (2013). Mendidik Anak ADHD. Depok: Javalitera.

PAI. (2016). Buga Rampai Penelitian Dalam Pendidikan Agama Islam. Yogyakarta: Penerbit Deepublish. 
Perdana, I. F. (2012). Lebih Paham dan Dekat dengan Anak ADD/ADHD. Yogyakarta: Grup Relasi Inti Media.

Prihartanta, W. (2015). Teori-Teori Motivasi. Jurnal Adabiya, 1(83), 1-11. https://doi.org/10.1111/j.15281167.2008.01808.x

Rejeki, S. (2014). 100 Tanya Jawab Soal. Yogyakarta: Mitra Buku.

Sardiman. (2014). Interaksi dan Motivasi Belajar Mengajar. Jakarta: PT RajaGrafindo Persada.

Satori, D., \& Komariah, A. (2014). Metodologi Penelitian Kualitatif. Bandung: Alfabeta.

Sugiyono. (2010). Metode Penelitian Kuantitatif Kualitatif Dan $R \& D$. Bandung: Alfabeta.
Sugiyono. (2014). Metode Penelitian Kombinasi (Mixed Method). Bandung: Alfabeta.

Sutrisno. (2013). Panduan Praktis Merawat dan Mendidik Anak dengan ADHD. Yogyakarta: Mitra Buku.

Syah. (2014). Psikologi Pendidikan. Bandung: PT Remaja Rosdakarya.

Tiel, J. M. Van. (2018). Anakku ADHD, Autisme, atau Gifted. Jakarta: Prenada Media Group.

Wijayani, N. A. (2014). Penenangan Usia Dini Berkebutuhan Khusus. Depok: ArRuzz Media.

Yusuf, M. (2014). Metode Penelitian. Jakarta: Prenadamedia. 